\title{
First record of Stephanostomum sp. Looss, 1899 (Digenea: Acanthocolpidae) metacercariae parasitising the pleasure oyster Crassostrea corteziensis (Hertlein) from the Mexican Pacific coast
}

\author{
M. I. GRANO-MALDONAD01,2, F. RUBALCAVA-RAMIREZ², A. RODRIGUEZ-SANTIAGO³, F. GARCIA-VARGAS4, \\ A. MEDINA-JASSO², M. NIEVES-SOTO2* \\ ${ }^{1}$ Universidad Autónoma de Occidente, Av. del Mar 1200, Flamingos, 82149, Mazatlán, Sinaloa, \\ *E-mail: marionievessoto@hotmail.com, marionievessoto@uas.edu.mx; ${ }^{2}$ Facultad de Ciencias del Mar, Universidad Autónoma \\ de Sinaloa, Paseo Claussen s / n. A. P. 610. Mazatlán, Sinaloa, México; ${ }^{3}$ CONACyT, Universidad Autónoma del Carmen, Facultad \\ de Ciencias Naturales, Av. Laguna de Términos s/n Col. Renovación 2da Sección, C.P. 24155 Ciudad del Carmen, Campeche, México; \\ ${ }^{4}$ Procesos Marinos y Acuícolas Ecointegrales S.A. de C.V.Sinaloa, México
}

Article info

Received October 24, 2018

Accepted April 10, 2019

\section{Summary}

The aim of this investigation was to identify the parasites present in the largely understudied pleasure oyster Crassostrea corteziensis in Sinaloa state in the northwestern Mexican Pacific coast. Inspection of twenty-eight oysters collected on "Ceuta" lagoon revealed the presence of the digenean Stephanostomum sp. (Digenea: Acanthocolpidae) cysts. Metacercariae were found encapsulated and embedded in the digestive gland and mantle tissue of oysters. The prevalence of infection revealed that $84.6 \%$ were infected, the abundance was 13.62, with a mean intensity of 16.09 per host. The members of this genus are characterized by a double crown of spines in the cephalic region surrounding the buccal opening of the worm. Significantly, we report the first incidence of the digenean Stephanostomum sp of the family Acanthocolpidae parasitizing Crassostrea corteziensis. Further we report that this bivalve is now considered a new intermediate host, and the northwestern Mexican Pacific coast is a new geographical distribution area for this digenean. The findings contribute to our understanding of the biology, biodiversity and host preference of these parasites, with implications for health risks posed by human consumption of the pleasure oyster.

Keywords: bivalve; digenean; trematode; parasites; helminth; oysters; Mexico
Introduction

There are some species of digenens that are known to employ mollusks and use them as definitive or final, intermediate or paratenic hosts for unidentified reasons. Digeneans are one of the most common groups of helminths found parasitising vertebrates. In Mexico, around 503 species have been reported in nearly 440 of the 4,697 species of vertebrates known and a total of 153 digenean species are endemic within Mexican territory (Perez-Ponce de Leon, 2001). Digeneans have a complex life cycle, involving one or two, but rarely more, intermediate hosts prior to infecting the definitive host. Many invertebrates may function as intermediate hosts for a wide variety of parasites. Bivalve mollusks play a key role as hosts for larval stages of digeneans, mainly trematodes (Lasiak, 1992; Ukong, 2007; Thieltges et al., 2006). Mollusk infection may occur through ingestion of the eggs or penetration by free-swimming larvae called miriacidia. Inside the first intermediate host, several different larval stages (i.e., sporocyst, redia, and cercaria) are formed by asexual reproduction. After emerging from the animal tissue, the larvae of trematodes (cercariae) may find a suitable secondary intermediate host i.e., a crustacean by transmission thru a trophic link (metacercariae-cyst) (Gomez del Prado et al., 2003; Grano-Maldonado \& Alvarez-Cadena, 2010) or a definitive host by active penetration until it reaches a vertebrate host. The mollusk-trematode model system which has been extensively studied is the host-parasite Biomphalaria-Schistosoma mansoni.

\footnotetext{
$\overline{\text { * - corresponding author }}$
} 
According to Lasiak (1992), the larvae of the bucephalid trematode sporocysts are found between the mantle tissue and visceral mass of intertidal mytilid bivalves from Chile. In Brazil, Ceuta \& Boehs (2012) reported that some parasites found in the mangrove mussel Mytella guyanensis (Lamarck, 1819) showed Rickettsia-like organisms, Nematopsis sp. (Apicomplexa), including a turbellarian, sporocysts and metacercariae of Bucephalus sp., and metacestodes of Tylocephalum sp. in the gills, mantle, and digestive gland. In Mexico, in a coastal lagoon of the southern Gulf of Mexico, Aguirre-Macedo et al., ( 2007) performed a parasite survey of the oyster Crassostrea virginica Gmelin, 1791. These authors found two protozoan (Nematopsis prytherchi and Perkinsus marinus), and 4 helminth species (Urastoma cyprinae, Proctoeces maculatus, Bucephalus sp., Tylocephalum sp.). However, in the Mexican Pacific coast, information about the parasite fauna of the pleasure oyster is almost absent.

The study of parasites in intermediate hosts is important for human health. For example, the host-parasite Biomphalaria-Schistosoma mansoni is responsible for human schistosomiasis (Hung et al., 2013; Hotez et al., 2014; Keiser \& Utzinger, 2009). Metacercarie Clinostomum complanatum has been mainly found in fish $P$. pardalis in the southwest of Mexico (Rodriguez-Santiago et al., 2016), and members of this species have been found attached to the human larynx and pharynx after eating raw seafood (Witenberg, 1944; García et al., 2007; Park et al., 2009). Thus, the consumption of raw fish and bivalves such as oysters potentially poses a health risk and should be explored further, motivating this study of parasites in the much understudied mollusk: the pleasure oyster Crassostrea corteziensis (Hertlein, 1951).

In the Sinaloa coast in northwest Mexico, the culture of the pleasure oyster is emerging as an important commercial alternative to the Pacific oyster Crassostrea gigas for oyster consumers. This mollusk is actively being cultured by local coastal communities for local consumption and commercial market (Chávez-Villalba et al., 2010; Chavez-Villalba 2014; Chávez-Villalba \& Aragón-Noriega, 2015). Research of oysters in the Pacific coast has focused on histopathological surveys revealing the presence of hypertrophied gametes, rickettsiales-like prokaryotes, the protozoan Perkinsus marinus, Nematopsis sp., Ancistrocoma, Sphenophrya-like ciliates, a turbellarian Urastoma sp., hyperparasite of the rickettsiales-like and copepods Pseudomyicola spinosus and Modiolicola gracilis (Cruz Flores \& Cáceres- Martínez, 2016; Caceres-Martinez et al., 1996, 1998, 1999, 2005, 2010, 2012, 2015, 2016; Costa et al., 2013; Da Silva et al., 2012, 2016; Dantas-Neto et al., 2015; Pinho et al., 2013).

The aim of this investigation was to identify for the first time the helminth parasites present in the pleasure oyster Crassostrea corteziensis in Sinaloa state in the northwestern Mexican Pacific coast to increase the current parasite life cycle and biological knowledge. Further research should consider the potential transmission to humans through consumption of this bivalve.

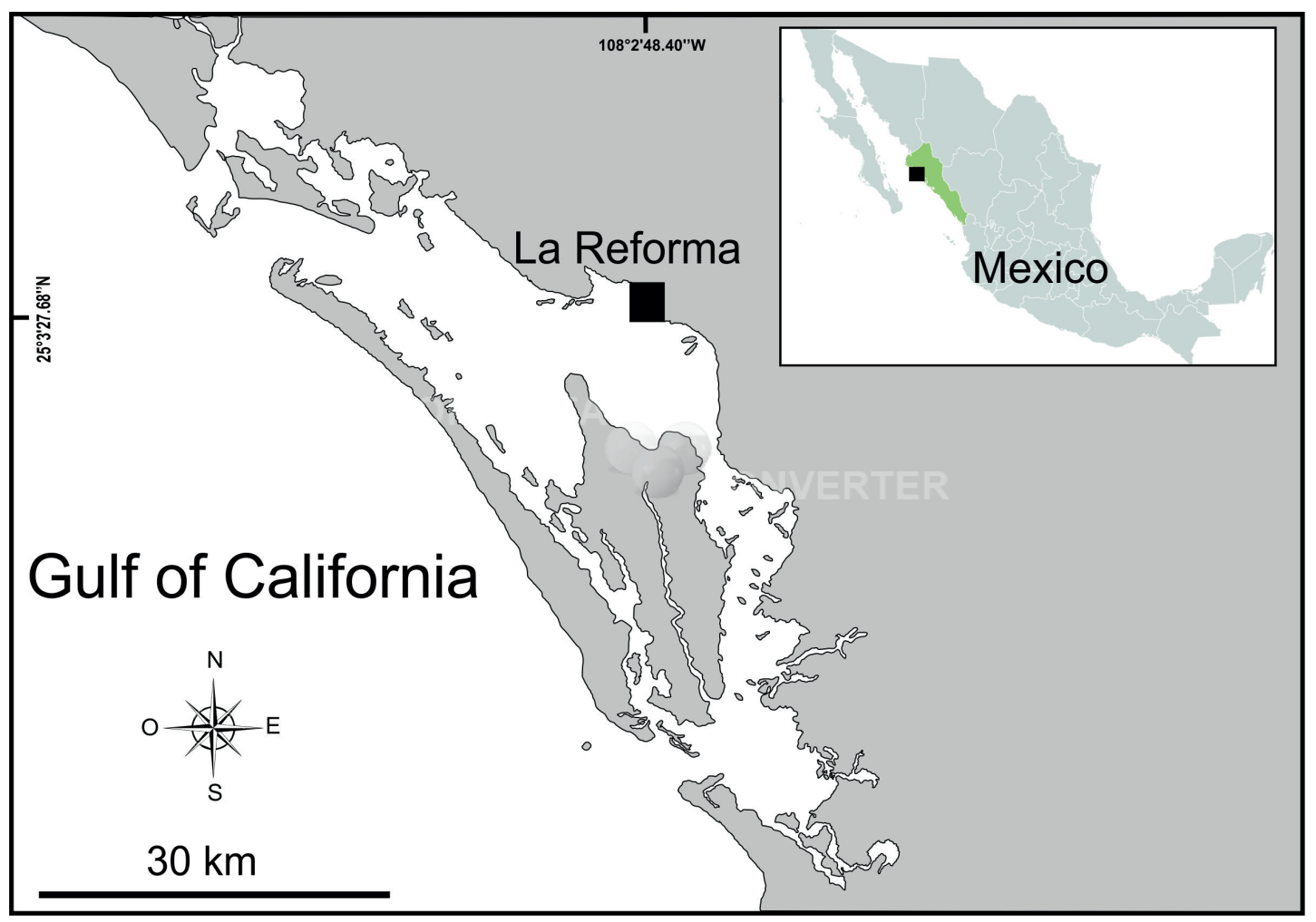

Fig. 1. Location of the collecting area of the pleasure oyster Crassostrea corteziensis on coast of Sinaloa, Mexico. 


\section{Materials and Methods}

\section{Source of parasites}

Twenty-eight pleasure oysters Crassostrea corteziensis (7.4 \pm $1.05 \mathrm{~cm}$ average length) were collected by hand from intertidal mudflats close to the mangrove roots from a local fish cooperative in 'Ceuta coastal lagoon, la Reforma' in the State of Sinaloa on the northwest Pacific coast of Mexico (25 3'27.68"N 108 2'48.40"W) (Fig. 1). The oysters were transported live to the Microalgae laboratory facilities at the Marine Science Faculty, Autonomous University of Sinaloa. Upon arrival, the organisms were place individually in $2 \mathrm{~L}$ aquaria supplied with filtered flow-through seawater and constant aeration. The oysters were fed daily with the microalgae Thalassiosira weissflogii (Grunow) around 241, $300 \mathrm{cel} / \mathrm{ml}$ for five days when all were sacrificed. Animal care and handling were carried out in accordance with Mexican laws (NOM-033-ZOO-1995). The oysters were dissected and organs were carefully separated on individual petri dishes with clean and filtered seawater then reviewed by compression between two $10 \mathrm{~cm}^{2}$ glass slides under a stereomicroscope (LEICA MZ 9.5, Wetzlar, Germany). Cysts were found in the mantle and digestive gland. The metacercariae were extracted from the cysts using small needles. The parasites were then mounted with a coverslip to flatten the specimens. AFA (a mixture of $85 \mathrm{ml}$ of ethanol, $25 \mathrm{ml}$ of formaldehyde, and $5 \mathrm{ml}$ of acetic acid) was added drop by drop to the edge of the coverslip to fix the parasites, and then they were made transparent with glycerin and mounted. Further observations were done with an optic microscope (LEICA DMLB 10, Wetzlar, Germany) for better resolution. In order to perform morphological descriptions, the parasites were observed under an optical microscope (100 x/oil immersion magnification).

The preparations were made for each parasite for their identification to the lowest taxonomical level. The taxonomic identification of the metacercariae found in this study was based on the work of previous studies (Bray \& Cribb, 2003; 2004; 2006; 2008; Bray et al., 2007).

\section{Ethical approval and/or Informed Consent}

Animal care and handling were carried out in accordance with institutional guidelines according to Mexican laws (NOM-033ZOO-1995).

\section{Results}

A total of 354 metacercariae cysts recovered from the 28 oysters host (Figs. $1-3$ ). The parasite was identified as a Stephanostomum Looss, 1899 (Digenea:Acanthocolpidae) by several charac-

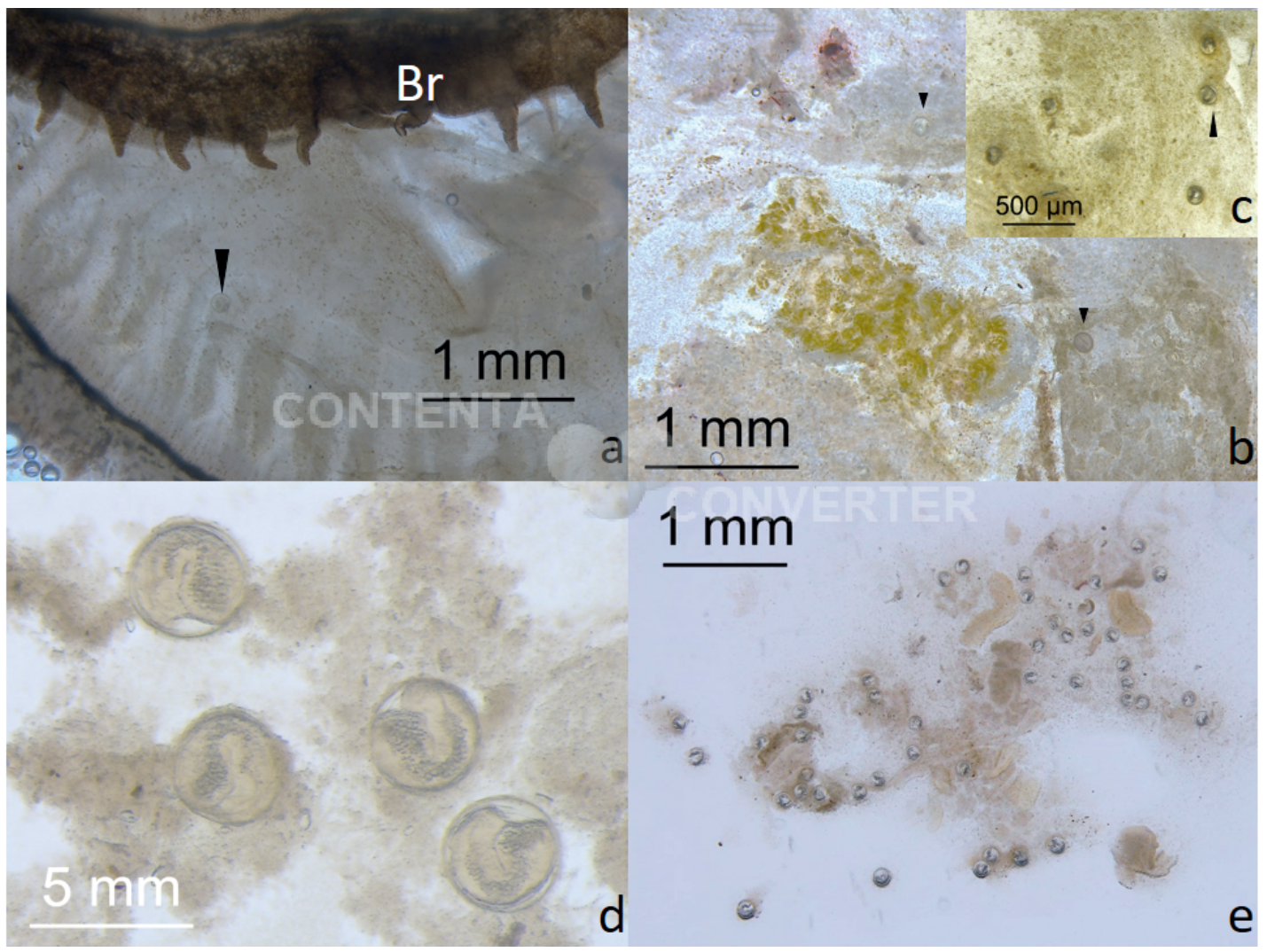

Fig. 2. Stephanostomum spp. (Digenea) from the pleasure oyster Crassostrea corteziensis. a-b) Cyst in the digestive gland. d-e) Cyst in the mantle. 


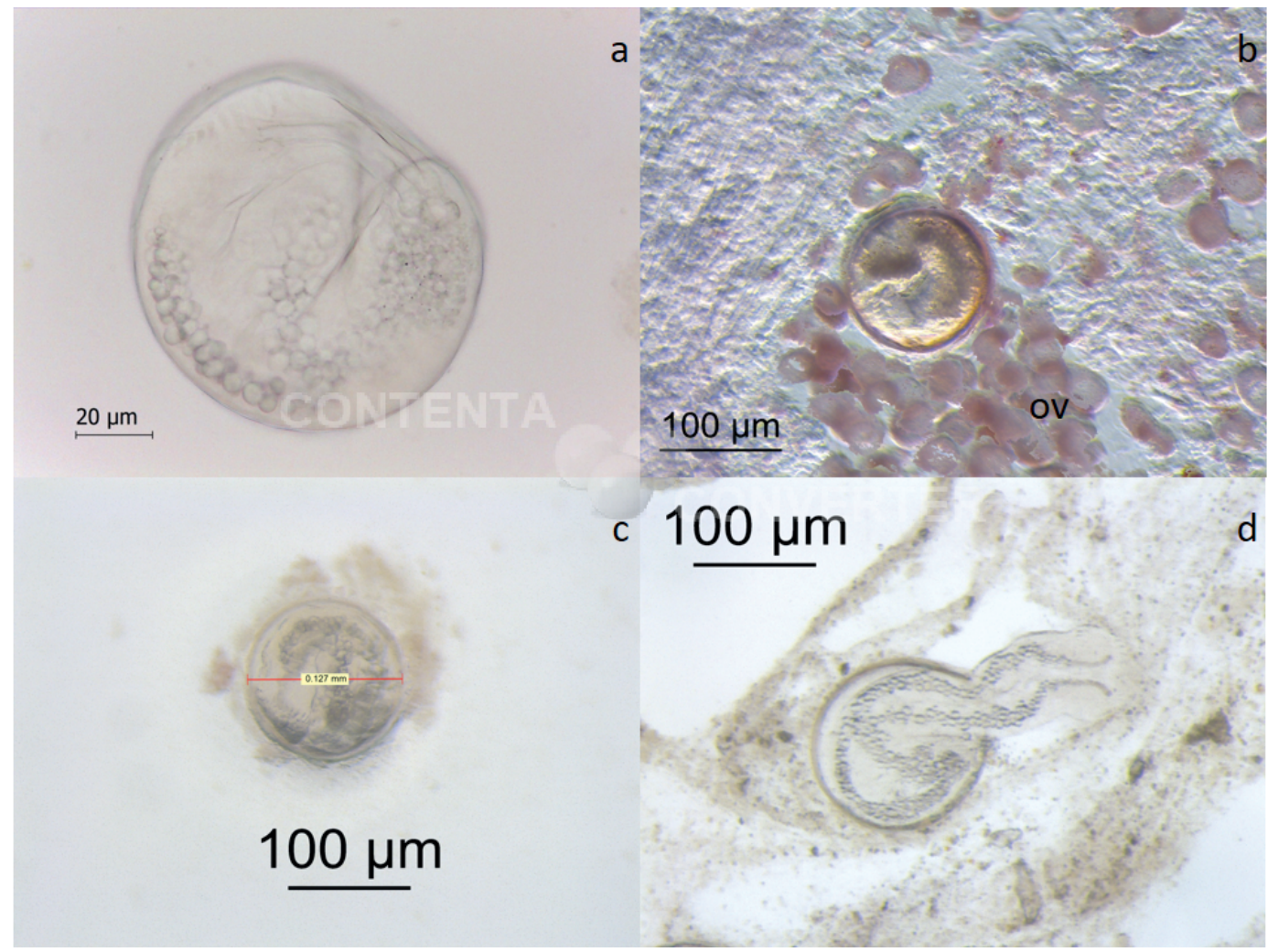

Fig. 3. Metacercariae Stephanostomum spp. (Digenea) were found encapsulated and embedded in the digestive gland and mantle tissue of oysters Crassostrea corteziensis a-d) individual cysts located in the mantle. b) cyst located close to the gonad, d) opened cyst to reveal the metacercariae.

teristics, particularly the double crown of spines in the cephalic region surrounding the buccal opening of the parasite (Fig. 3). Exemplars were registered (catalogue number: 10630) in the CNHE-IBUNAM. The prevalence was $84 \%$, and the abundance was 13. The mean intensity was 16 per host and the number of parasites per host varied from 1 to 56 .

\section{Taxonomic Remarks}

Parasite: Stephanostomum sp. Looss, 1899 (Digenea: Acanthocolpidae)

Type-host: the pleasure oyster Crassostrea corteziensis (Hertlein) (Molluska: Bivalvia)

Habitat: Intertidal mudflats

Site of infection: mantle and digestive gland

Type-locality: Ceuta coastal lagoon Sinaloa, México 253'27.68”N

$108^{\circ} 2$ '48.40"W

Date collection: November 2017

Deposition of specimens: CNHE-IBUNAM- 10630

Recent and extensive studies (Bartoli \& Bray, 2001; Saoud et al., 2002, Bray \& Cribb, 2003; Bartoli \& Bray, 2004) point out that Stephanostomum sp. Looss, 1899 is an extremely large genus. It is composed of 112 species nominally distributed around the world that infect a considerable number of teleost fishes, particularly those of temperate waters (Bartoli \& Bray, 2001). Cribb et al., (2001) revised the overall pattern of specificity of trematodes in fishes and first intermediate hosts. The acanthocolpid fauna of fishes from Australian and South Pacific waters is very well known. Cribb et al., (2001) inferred that this family Acanthocolpidae is consistent with the overall mollusk pattern. Agreeing with Barnet et al., (2010) who performed and extensive review, the success of this genus is marked by the extensive range of fishes (over 70 families) that are infected as adults. Species of Stephanostomum reported from eastern Australian waters include S. adlardi, S. aaravi, S. bicoronatum, S. carangi, S. cobia, S. ditrematis, S. hawaiiense, S. lamothei, S. madhaviae, S. nyoomwa, S. pagrosomi, S. petimba, S. talakitok, S. tantabiddii, S. tupatupa, and S. cf. uku. Barnet et al. (2010) reported that there are nine families of trematodes that routinely infect bivalves as first intermediate hosts and a few others (e.g. Lepocreadiidae, Hemiuridae) that infect them exceptionally. However, far more host-parasite records may need to be accumulated for better understanding of the relationships in the Acanthocolpidae group. Our results agree with Barnet et al., (2010) and Cribb et al., (2002) who reported that i) Stephanostomum was the second largest genus of trematodes of fishes, ii) the genus also appears to have low specificity for first intermediate hosts, and iii) given the current size of the genus there are clearly many more intermediate hosts to be found within and beyond the mollusk. In the present study, Stephanostomum was found in the pleasure oyster Crassostrea corteziensis in the northwest of the Pacific coast of Mexico. In Mexico, the species of this type of digenan is widely 
distributed in marine fish, according with Lamothe-Argumedo et al., (1997) where eight species that parasitize fish of different families have been recorded (S. californicum Manter and Van Cleave, 1951 in the intestine of Genyonemus Californucum California, USA; S. casum was collected from the intestine of Microlepidotus brevipinnis in Chamela Bay, Jalisco, S. dentatum (Linton, 1910) Linton, 1940 of the intestine of Balistes polylepis and Paralicthys californicus of Baja California; S. ditrematis collected in the stomach of Seriola dorsalis captured on the Partida Island; Baja California Sur; S. hispidum (Yamaguti, 1934) of Caranx hippos in Manzanillo, Colima; S. megacephalum Manter, 1940 collected in the intestine of Caranx hippos in the Bay of Chamela, Jalisco; $S$. tenue Linton 1898 collected from the Selar crumenophthalmus fish from Puerto Vallarta, Jalisco in members of the Lutjanidae family (Garcia-Vargas, 2010).

The members of this genus are characterized by a double crown of spines in the cephalic region surrounding the buccal opening of the worm. Bray et al., (2005) pointed out that the characteristic with the highest taxonomic load to separate the species of this genus is the number of spines that surround the mouth, but this is not a regular pattern. The identification for species level could not be carried out as the parasites in our study displayed a greater number of circumoral spines 63 (58-64, arranged in oral 28-32 and 30 - 32 suboral). Additionally, molecular identification of these parasites merits further investigation to better determine accurate taxonomic status.

We found that the pleasure oyster acts as an intermediate host having infective stages of Stephanostomum sp. Looss, 1899 (Digenea:Acanthocolpidae) parasites. Members of the genus Stephanostomum have been studied comprehensively in Australia (Bray \& Cribb, 2003; 2004, 2004a; 2005; 2008; Bray et al., 2007) where adult stages were present in fishes of the family Carangidae and Scombrids. Based on our contribution in which we identified the parasitic larval stages metacercarie existing in Crassostrea corteziensis, further research should consider the potential transmission to humans through consumption of this bivalve.

\section{Discussion}

This study is the first report identifying the metacercariae of Stephanostomum species, a digenean of the family Acanthocolpidae, parasitising the pleasure oyster Crassostrea corteziensis (Hertlein) from the Mexican Pacific Coast. According to Caceres-Martinez et al., (2016) other pathogens like Perkinsus marinus seems to represent a more significant risk for the health of pleasure oysters than do other parasites, and surveillance and control of these parasites are needed for the development of pleasure oyster culture. However, in our study the majority of parasitised oysters appeared

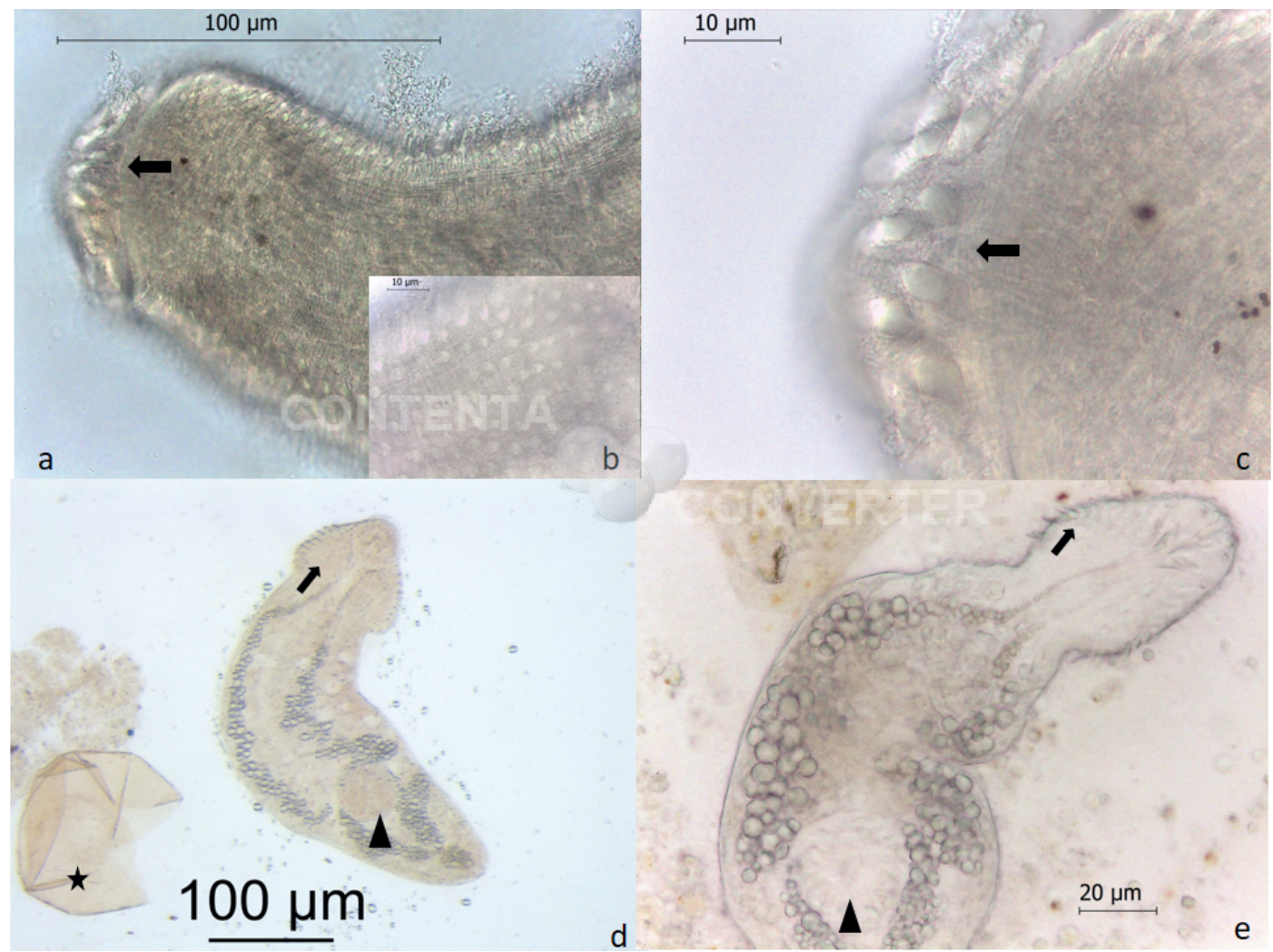

Fig. 4. Microphotography using an optical microscope of cyst released metacercariae of Stephanostomum spp. (Digenea). a-d) noticed the a double crown of spines in the cephalic region (arrow) surrounding the buccal opening of the worm; d-e) acetabulum (arrow head), empty cyst (star). 
to be free of infection and no apparent destruction of the host's gonadal tissue, digestive or branchial damage was observed. In the parasitological study performed by Aguirre-Macedo et al. (2007) the prevalence and mean abundances for the protozoa and helminths varied widely between locations but were generally below $50 \%$. Nematopsis prytherchi and the Tylocephalum sp. were the most prevalent species (>60\%). Perkinsus marinus was present in oysters of eight coastal lagoons and had low prevalence $(<30 \%)$ in almost all samples. All identified protozoa and helminths are widely distributed in the Gulf of Mexico and are common oyster parasites. Only P. marinus and the Bucephalus sp. were associated with damage to host tissues. In our study the prevalence of Stephanostomum species infection was $84.6 \%$, the abundance was 13.62 and the mean intensity of 16.09 per host. These results revealed a high percentage of parasitism in the zone, this is alarming since the typical consumption of this animal is uncooked. It is important to mention that most human-parasite disease transmission is mainly associated with the consumption of raw seafood dishes i.e., sushi, sashimi, ceviche (Kuchta et al., 2005ab). Most of the species potentially pathogenic to human are pathogenic mostly in larval stage, i.e., L1 and L3 in nematodes, plerocercoid in cestodes and metacercariae in digenan trematodes (Rodriguez-Santiago et al., 2016). Consequently, the ingestion of bivalves such as oysters as a source of raw food may have a health risk factor and should be explored further.

Barnet et al., (2010) reported in the case of other Stephanostomum spp. cercariae from mollusks (Gastropoda: Nassariidae) in Australia. Their results suggest that parasite location in the host was similar to our findings (Digestive gland, gonads) and the habitat of bivalve collection of intertidal mudflats was similar with a prevalence of emergence: $0.57 \%$ (10 of 1766 Nassarius dorsatus), $0.21 \%$ (4 of 1908 Nassarius olivaceus). In our study, the parasite Stephanostomum sp.was also present in a costal lagoon in Sinaloa state in quantities greater than $84.6 \%$. With respect to the digenetic trematodes, the presence of metacercariae observed in our study reveals that bivalves may serve as potentially primary and secondary intermediate hosts at the same time.

A limitation of this study is that molecular techniques could not be used because the samples were preserved on formalin. Future comparison of the $18 \mathrm{~S}$ ribosomal RNA gene (or other conserved genes) sequence of the parasite collected from pleasure oysters should be conducted. There is no doubt, nonetheless, that infections by parasites have major consequences for species of host in natural conditions and must consequently be considered as a fundamental factor within any system of aquaculture.

\section{Conflicts of Interest}

Authors have no potential conflict of interest pertaining to this submission to Helminthologia.

\section{Acknowledgements}

We would like to thank P. Piña, head of the Microalgae Laboratory at the Faculty of Marine Sciences-UAS for providing materials, equipment to maintain alive the donated organisms. A. Rodríguez thanks (CONACyT /research fellow no.3168). We thank M. Manzano for animal donation and the use of the stereomicroscope, L. Ordoñez for help with the animal laboratory maintenance, L. Rodríguez, F. Flores and O. Millán for their support in the collection and transport of the organisms. Special thanks to the two anonymous reviewers and the subject editor for their valuable suggestions.

\section{References}

Aguirre-Macedo, Ma.L, Simá-Alvarez, R.A., Román-Magaña, M.K., GüEMEZ-RICALDE, J.I. (2007):Parasite survey of the eastern oyster Crassostrea virginica in coastal lagoons of the southern Gulf of Mexico. J. Aquat. Anim. Health,19(4): 270 - 279. DOI: 10.1577/ H06-050.1

Barnett, L.J. Mlller, T.L., CRibB, T.H. (2010): Two New Stephanostomum - Like Cercariae (Digenea: Acanthocolpidae) from Nassarius dorsatus and N. olivaceus (Gastropoda: Nassariidae) in Central Queensland, Australia. Zootaxa, 2445: 35 - 52

Bartol, P., Bray, R.A. (2001): Contribution to the knowledge of species of the genus Stephanostomum Looss, 1899 (Digenea: Acanthocolpidae) from teleosts of the Western Mediterranean, with the description of S. gaidropsari n. sp. Syst. Parasitol., 49: $159-188$

Bartoli, P., Bray, R.A. (2004): Four species of Stephanostomum Looss, 1899 (Digenea, Acanthocolpidae) from Seriola dumerili (Risso) (Teleostei, Carangidae) in the Western Mediterranean, including S. euzeti n. sp. Syst. Parasitol., 58: 41 - 62

BrAY, R.A., CRIBB, T.H. (2004): Stephanostomum tantabiddii n. sp. (Digenea: Acanthocolpidae) from Carangoides fulvoguttatus (Forsskål, 1775) (Perciformes: Carangidae), from Ningaloo Reef, Western Australia. Zootaxa, 457: 1-8

Bray, R.A., CribB, T.H., Waeschenbach, A., Littlewood, D.T.J. (2007): A new species of Stephanostomum Looss, 1899 (Digenea: Acanthocolpidae) with a bizarre oral sucker: $S$. adlardi n. sp. from the common coral trout Plectropomus leopardus (Lacepède, 1802) (Perciformes: Serranidae) from Lizard Island, Great Barrier Reef. Acta Parasitol., 52: 206 - 212. DOI: 10.2478/s11686-007-0025-0

BraY, R.A., CriBb. T.H. (2003): Species of Stephanostomum Looss, 1899 (Digenea: Acanthocolpidae) from fishes of Australian and South Pacific waters, including five new species. Syst. Parasitol., 55: $159-197$

BraY, R.A., CriBb. T.H. (2006): Stephanostomum talakitok n. sp. (Digenea: Acanthocolpidae) from Gnathanodon speciosus (Perciformes: Carangidae) from Ningaloo Reef, Western Australia. Zootaxa, 1104: $59-68$

BraY, R.A., CRIBB. T.H. (2008): Stephanostomum spp. (Digenea: 
Acanthocolpidae) from scombrids and carangids (Perciformes) from the Great Barrier Reef, with the description of two new species. Rev. Mex. Biodiv., 79: 49S - 68S

Bray, R.A., Webster, B.L., Bartoli, P., Littlewood, D.T.J. (2005): Relationships within the Acanthocolpidae Lühe, 1906 and their place among the Digenea. Acta Parasitol., 50: 281 - 291

Cáceres-Martínez, C., Chávez -Villalba, J., Garduño-Méndez, L. (2005): First record of Pseudomyicola spinosus in Argopecten ventricosus in Baja California. J. Invertebr. Pathol., 8(9): 295 100. DOI: 10.1016/j.jp. 2005.03.004

Cáceres-Martinez, J.A., Vasquez Yeomans, R., Cruz Flores, R. (2015): First description of symbionts, parasites, and diseases of the Pacific geoduck Panopea generosa from the Pacific coast of Baja California, Mexico. J. Shellfish Res., 34(3): 751 - 756. DOI: 10.2983/035.034.0304

Cáceres-Martínez, J.. Vásquez-Yeomans, R., Padilla-Lardizábal, G. (2010). Parasites of the Pleasure Oyster Crassostrea corteziensis cultured in Nayarit, Mexico. J. Aquat. Anim. Health., 22(3): 141 51. DOI: $10.1577 / \mathrm{H} 09-052.1$

Cáceres-Martínez, J. Vásquez-Yeomans,. R. (1999): Metazoan parasites and pearls in coexisting mussel species: Mytilus californianus, Mytilus galloprovincialis and Septifer bifurcatus, from an exposed rocky shore in Baja California, NW México. Veliger, 42: $10-16$

Cáceres-Martínez, J., Ortega, M.G., Vásquez-Yeomans, R., Garcia, T.DE J., STOKES, N.A. (2012): Natural and cultured populations of the mangrove oyster Saccostrea palmula from Sinaloa, México, infected by Perkinsus marinus. J. Invertebr. Pathol., 110: 321 - 325. DOI: 10.1016/j.jp.2012.03.019

Cáceres-Martínez, J., Vásquez-Yeomans, R,. Padilla-Lardizábal, G. (2010): Parasites of the pleasure oyster Crassostrea corteziensis cultured in Nayarit, México. J. Aquat. Anim. Health., 22: 141 - 151. DOI: 10.1577/H09-052.1

Cáceres-Martinez, J., Vásquez-Yeomans, R. Padilla-Lardizábal G., Del Rio-PoRTILLA, M.A. (2008): Perkinsus marinus in pleasure oyster Crassostrea corteziensis from Nayarit, Pacific Coast of México. J. Invertebr. Pathol., 99: 66 - 73. DOI: 10.1016/j.jp.2008.03.005 Cáceres-Martinez, J., Vásquez-Yeomans, R., Sluys., R.(1998): The turbellarian Urastoma cyprinae (Platyhelminthes: Urastomidae) associated with natural and commercial populations of Mytilus galIoprovincialis and Mytilus californianus from Baja California, NW México. J. Invertebr. Pathol.,72: 214 - 219

Cáceres-Martínez, J., Vásquez-Yeomans, R., Suárez-Morales, E., (1996): Two parasitic copepods, Pseudomyicola spinosus and Modiolicola gracilis associated with edible mussels, Mytilus galloprovincialis and Mytilus californianus from Baja California NW México. J. Shellfish Res., 15: $45-49$

Cáceres-Martinez, J., Madero-López, L.H., Padilla-Lardizábal, G., VÁsquez-Yeomans, R. (2016): Epizootiology of Perkinsus marinus, parasite of the pleasure oyster Crassostrea corteziensis, in the Pacific coast of Mexico. J. Invertebr. Pathol., 139(12): 12 - 18. DOI: 10.1016/j.jp.2016.07.003
CeutA, Lo., Boens, G. (2012): Parasites of the mangrove mussel (Bivalvia: Mytilidae) in Camamu Bay, Bahia, Brazil. Braz. J. Biol., 72(3): 421 - 427. DOI: 10.1590/S1519-69842012000300002

Chávez-VIllalba, J., (2014): Cultivo de ostión Crassostrea gigas: Análisis de 40 años de actividades en México [Cultivation of the oyster Crassostrea gigas: Analysis of 40 years of activities in Mexico]. Hidrobiológica, 24(3):175 - 190 (In Spahish)

Chávez-VIllalba, J., Aragón-Noriega, E.A., (2015): Modeling the individual growth of the Cortez oyster Crassostrea corteziensis (Bivalvia: Ostreidae) from central Gulf of California. Cah. Biol. Mar., 56: 231 - 236. DOI: 10.21411/CBM.A.42B0E95F

Chávez-Villalba, J., Arreola-Lizárraga, A., Burrola-Sánchez, S., Hoyos-ChAIREZ, F. (2010): Growth, condition, and survival of the Pacific oyster Crassostrea gigas cultivated within and outside a subtropical lagoon. Aquaculture, 300: 128 - 136. DOI: 10.1016/j. aquaculture.2010.01.012

Costa, S., Vasconcelos Gesteira., R.T.C., Magenta, A., Magalhäes, R. (2013): Parasitological survey of mangrove oyster, Crassostrea rhizophorae, in the Pacoti River Estuary, Ceará State, Brazil. J. Invertebr. Pathol., 112 (1): 24 - 32. DOI: 10.1016/j.jip.2012.10.004 CRIBB, T.H., BRAY, R.A., LITTLEWOOD, D.T.J. (2001): The nature and evolution of the association between digeneans, molluscs and fishes. Int. J. Parasitol., 31(9): 997 - 1011. DOI: 10.1016/S00207519(01)00204-1

CribB, T.H., Chisholm, L.A., Bray, R.A. (2002): Diversity in the Monogenea and Digenea: does lifestyle matter? Int. J. Parasitol., 32: 321 - 328. DOI: 10.1016/S0020-7519(01)00333-2

Cruz Flores, R., Cáceres- Martínez, C. (2016): The hyperparasite of the rickettsiales-like prokaryote, Candidatus Xenohaliotis californiensis has morphological characteristics of a Siphoviridae (Caudovirales). J. Invert. Pathol., 133: 8 - 11. DOI: 10.1016/j. jip.2015.11.006

Da Silva, P., Magalhães, A., Barracco, M. (2012): Pathologies in commercial bivalve species from Santa Catarina State, southern Brazil. J. Mar. Biolog. Assoc. U.K., 92(3): 571 - 579. DOI: 10.1017/ S0025315411001007

Da Silva., M., Pereira Costa, P., Paiva Bragante De Araújo, C., Ramos Queiroga, F., Wainberg, A. (2016): Epizootiology of Perkinsus $\mathrm{sp}$. in Crassostrea gasar oysters in polyculture with shrimps in northeastern Brazil. Rev. Bras. Parasitol. Vet., 25(1): 37 - 45. DOI: 10.1590/S1984-29612016011

Dantas-Neto, M.P. Sabry, R.C. FerreiRa, L.P. Romão, L.S., MaggioNI, R. (2015): Perkinsus sp. infecting the oyster Crassostrea rhizophorae from estuaries of the septentrional Northeast, Brazil. Braz. J. Biol., 75 (4): 1030. DOI: 10.1590/1519-6984.06314

Garcia, H.H., MoRo, P.L., SCHANTZ, P.M. (2007): Zoonotic helminth infections of humans: echinococcosis, cysticercosis and fascioliasis. Curr. Opin. Infect. Dis., 20(5): 489 - 494. DOI: 10.1097/ qco.0b013e3282a95e39

GARCIA-VARGAS, F. (2010): Helmintos parásitos del pargo lunarejo, Lutjanus guttatus Teindachner, 1869 (Pisces: Lutjanidae) en dos localidades del Pacífico mexicano y estructura de las comu- 
nidades de endohelmintos [Helminth parasites of the snapper, Lutjanus guttatus Teindachner, 1869 (Pisces: Lutjanidae) in two localities of the Mexican Pacific and the endohelminth structure]. PhD Thesis, Sinaloa, Mexico. Research Center in Food and Development (In Spanish)

Gómez Del Prado, Ma. C., Alvarez-Cadena, J., Lamothe-Argumedo, R., Grano-Maldonado, M. (2003): Cymatocarpus solearis a brachycoeliid metacercaria parasitizing Panulirus argus (Crustacea: Decapoda) from the Mexican Caribbean Sea. An. Inst. Bio., 74 (1): $1-10$

Grano-Maldonado, M., Álvarez-Cadena, J. (2010): In vitro cultivation of metacercariae of Cymatocarpus solearis (Brachycoeliidae) to obtain the adult stage without the definitive turtle. Korean J. Parasitol., 48 (1): 49 - 55. DOI: 10.3347/kjp.2010.48.1.49

Hotez, P.J., Alvado, M., Basáñez, M.-G., (2014): The global burden of disease study 2010: interpretation and implications for the neglected tropical diseases. PLoS Negl. Trop. Dis., 8(7): e2865. DOI: 10.1371/journal.pntd.0002865.e2865

Hung, N.M., Madsen, H., Fried, B. (2013): Global status of fishborne zoonotic trematodiasis in humans. Acta Parasitol., 58(3): 231 - 258. DOI: 10.2478/s11686-013-0155-5

KeISER, J., UtzInger, J. (2009): Food-borne trematodiases. Clin Microbiol Rev., 22(3): 466 - 483. DOI: 10.1128/CMR.00012-09

KuchtA, R., Scholz, T., Brabec, J., Wich, B. (2015a): Diphyllobothrium, Diplogonoporus and Spirometra. In: XIAO L, RYAN U, FENG F. (Eds) Biology of foodborne parasites. Section III. Important foodborne helminthes. Boca Raton FL: CRC Press; p. 299 - 326

Kuchta, R., Serrano-Martine, M., Scholz T. (2015b): Pacific broad taperworm Adenocephalus pacificus as a causative agent of globally reemerging Diphyllobothriosis. Emerging Infect. Dis., 21(10): 1697 - 1703. DOI: 10.3201/eid2110.150516

Lamothe-Argumedo, M.R., Garcia-Prieto, L. Osorio Sarabia D. Perez Ponce De Leon. G. (1997): Catálogo de la Colección Nacional de Helmintos. Instituto de Biología, Universidad Nacional Autónoma de México UNAM, Comisión Nacional de Biodiversidad
CONABIO. México [Catalog of the National Collection of Helminths]. Institute of Biology, National Autonomous University of Mexico. National Commission of Biodiversity, Mexico (In Spanish) LASIAK, T. (1992): Bucephalid Trematode infections in mytilid bivalves from the rocky intertidal of southern Chile. J. Molluscan Stud., 58 (1): 29 - 36. DOI: 10.1093/mollus/58.1.29

PARK, C.W., KIM, J.S., Joo., H.S., KIM, J. (2009): A human case of Clinostomum complanatum infection in Korea. Korean J. Parasitol., 47: 401 - 404. DOI: 10.3347/kjp.2009.47.4.401

Perez-Ponce De Leon, G. (2001): The diversity of digeneans (Platyhelminthes: Cercomeria: Trematoda) in vertebrates in Mexico. Comp. Parasitol., 68: 1 - 8

Pinho Brandão, R., Guisla, B., Da Silva, P. (2013): Health assessment of the oyster Crassostrea rhizophorae on the southern coast of Bahia, northeastern Brazil. Rev. Bras. Parasitol Vet., 22(1): 84 - 91. DOI: 10.1590/S1984-29612013005000007

Rodriguez-Santiago, M., Garcia-Prieto, L., Mendoza-Garfias, B., González-Solis, D., Grano-Maldonado, M.I. (2016): Parasites of two coexisting invasive sailfin catfishes (Siluriformes: Loricariidae) in a tropical region of Mexico. Neotropical Ichthyol., 14(3): e160021. DOI: 10.1590/1982-0224-20160021

SAOud, M.F.A. (1976):Trematodes of the genus Stephanostomum Looss, 1899 (Digenea: Acanthocolpidae Lühe, 1901), with description of Stephanostomum qatarense n. sp. and redescription of Stephanostomum triacanthi Madhavi. Riv. Parassitol., 29: 87 - 103 Thieltges, D.W., Krakau, M., Andresen, H., Fottner, S., Reise, K. (2006): Macroparasite community in molluscs of a tidal basin in the Wadden Sea. Helg. Mar. Res., 60: 307 - 316

Ukong, S., Krallas, D., Dangprasert, T., Channgarm, P. (2007): Studies on the morphology of cercariae obtained from freshwater snails at Erawan Waterfall, Erawan National Park, Thailand. Southeast Asian J. Trop. Med. Public Health, 38(2): 302 - 312 WitenBerg, G. (1944): What is the cause of the parastic laryngo-pharyngitis in the near East "Halalzoun"? Acta Med. Orient., 3 (6): $191-192$ 